\title{
Supervision System in the Financial Management of State-owned Enterprises
}

\author{
Rui Li \\ Huanghe Science \& Technology College; Zhengzhou 450006, China
}

\begin{abstract}
Financial management is an important guarantee for the survival and development of state-owned enterprises in the market economy, and the financial management system is of great significance to them. In the process of financial system reform, special attention should be given to the reform of the supervision system. The combination of management reform and institutional innovation should be highlighted, which can be interpreted as two aspects: one is the implementation of management responsibilities and the other is the innovation of system construction. State-owned enterprises should refer to the management model of outstanding non-state-owned enterprises and implement it into various aspects combining with own characteristics and historical background: it can be implemented into the financial supervision to ensure efficient and transparent financial management; it can be implemented into the construction of performance evaluation platform to enhance the efficiency of management and improve management efficiency of state-owned enterprises; it can be implemented in to the introduction of information technology to promote constant update of management technologies of state-owned enterprises.
\end{abstract}

Keywords: financial supervision; system reform; financial management; state-owned enterprise characteristic.

\section{Introduction}

From the perspective of overall trend, although the financial supervision system of state-owned enterprises is increasingly improved, there are still some problems. In this context, enterprises need to perfect their own management mode while the government needs to perfect relevant policies.

\section{Research Background and Current Situation of China}

\subsection{Background}

China's state-owned enterprises have gone through 30 years of enterprise reform. But the effect is not very ideal and they are still far from the operation and management mode of modern enterprises. The owners of China's state-owned enterprises are the entire Chinese people because of the special social nature and history background. This makes the owner of state-owned enterprises become a vague concept, resulting in the "absence" of the owner of state-owned enterprises. In the case that the owner is ambiguous, the actual operation situation of the state-owned enterprise will not directly affect the benefits of its owners. Without any reward and punishment mechanism encouraging or restraining the state-owned enterprise, it will not update and develop itself constantly driven by benefits. In face of this difficulty, we need to recognize that the low overall operation efficiency of state-owned enterprises has a lot to do with their unclear ownership. It is a fact that Chinese law stipulates the special status of state-owned enterprise workers and safeguards their stable benefits. It is difficult to change, which adds certain difficulty to the reform of state-owned enterprises. However, it can be seen from the more than 30 years of reform experience that the separation of administration from management is the prerequisite for great reforms of state-owned enterprises.

\subsection{Current Situation of China}

There have been few systematical researches on financial supervision so far in the academic circles of China. Researchers at present generally start from their research directions to explore the characteristics and law of financial supervision in a certain aspect. Due to this, the current research results are relatively fragmented and most researches only focus on one aspect while overall research lacks. Moreover, the fact that research achievements of some perspectives are very rich while the 
achievements of some perspectives are very few is unfavorable for later scholars to conduct conclusion and summary. What the author summarizes is showed as following.

\subsubsection{Financial supervision and financial management}

The managing scope of financial management includes problems in the cash flow and implementation of the path of cash flow; it also covers control of the enterprise -- if it is a limited liability company, the managing scope covers the distribution of shares, leveraged buyouts and many other aspects. With the deepening of enterprise reform, state-owned enterprises attach increasing importance to the finance management, and management functions achieve rough distribution with the establishment of a clearly hierarchy management pattern. At the same time, the corresponding financial supervision system is also established and improved step by step.

\subsubsection{Financial supervision mechanism}

The modern enterprise theory has been relatively mature in the aspect of enterprise financial management. State-owned enterprises can create driving force for their own development by the in-depth understanding of managerial experiences based on study and research on modern enterprise theories. In the current academic circles, the study of modern enterprise management theories has made certain progress. Some Chinese financial experts had put forward that the corporate finance can be divided into operator finance and stakeholder finance.

\section{Background and Characteristics of State-owned Enterprises}

\subsection{Background of state-owned enterprises}

As an important component of Chinese market economy, state-owned enterprises have attracted much attention.

1. International background

The global financial crisis triggered by the subprime crisis of the United State led to the widespread economic recession. Many countries and regions have not been completely out of the crisis. In view of the important position of state-owned enterprises in the market, the government firmly controls the economic operation in the economic crisis, eventually minimizing the harm caused by the economic crisis.

\section{Domestic background of China}

The trend of current Chinese economy is unclear. Some scholars believe that Chinese economy has entered into a "deep end" and "crucial stage". It encounters development difficulties and is difficult to keep the high-speed growth as it did before. As state-owned enterprises play an important part in Chinese economy, the barriers of state-owned enterprise development will also hinder the development of the national economy. This is why state-owned enterprise reform should be deepened constantly.

3. The development direction

The report to the 18th National Congress of the Communist Party of China has pointed out the direction for the current economic development. It again put forward "deepening the reform of state-owned enterprises" and placing the reform of state-owned enterprises in the height of national development strategy.

\subsection{State-owned enterprise characteristics}

The state-owned enterprise is different from general enterprises. In the aspect of property ownership, the property owner of general enterprises is the enterprise as a legal person. But the ownership of the state-owned enterprise belongs to the state and the entire people. Therefore, operators of state-owned enterprises only have the power of administration and no ownership. Due to the lack of ownership, China's state-owned enterprises show obvious differences from other enterprises in the market economy.

The first one is the property right of state-owned enterprises. The property right of the state-owned enterprise, for legal purposes, belongs to entire people, a group unable to manage the enterprise together. Thus, the entire people entrust property rights to the government and then the government exercises certain property rights on behalf of them. 
The second one is the social responsibility undertaken by state-owned enterprises. State-owned enterprises control the lifeblood of the market economy and play a leading role under the current system of government of China. For China, they play an indispensable role in stabilizing the system of government and maintaining the national nature. At the same time, state-owned enterprises also bear certain social responsibilities, such as guaranteeing the fairness of social allocation. Compared with private enterprises, state-owned enterprises need to assume more responsibilities and give consideration to the harmonious development of all aspects. Therefore, the economic benefit cannot be regarded as the only standard to evaluate the development situation of a state-owned enterprise. To ensure state-owned enterprises fulfilling their social responsibilities, it needs to develop relevant systems and policies on the basis of existing laws, so as to guarantee the implementation.

Finally, state-owned enterprises need to improve production efficiency. One of the biggest problems of state-owned enterprises is the excessively low production efficiency which lowers the state's overall economic development level to a certain extent. Although special attention has been given to this problem in the more than thirty years of the state-owned enterprise reform, there is no substantive progress. The state-owned enterprise holds strong rights in the respect of finance, which can improve the efficiency of decision-making to a certain extent. But the financial power is likely to be abused in the absence of regulation, leading to unreasonable planning or waste of resource. If financial rights of the operators are limited, they have to obtain approval at all levels, which will affect the enterprise execution. This is also not conducive to enterprise development.

\section{Existing Problems of the Financial Supervision System of State-owned Enterprise}

Now, state-owned enterprises have established a relatively standard and complete supervision system for the financial system management, thereby achieving the effect of internal equilibrium. However, the financial supervision system has a variety of problems in the actual operation due to various reasons.

The effective supervision to important decisions of managers is absent. The board of directors of the state-owned enterprise has great power in finance and other aspects. Directors can discuss the enterprise financial decision and the decision can be put into implementation when it is unanimous. There is board of supervisors in the state-owned enterprise and it participates in the decision-making. But, it does not greatly affect the determination and implementation of decision and its supervision power is impracticable, because it only has supervision power but has no voting right.

The supervision to the personal economic situation of operators and managers of the state-owned enterprise is absent. State-owned enterprises fully guarantee the benefits of managers and employees. But the management's consumption by public funds is not explicitly stipulated. There is no supervision system for position-related consumption of management, so that the boundary of consumption by public funds is easy to be blurred. This undoubtedly increases consumption and expenditure.

The intermediary financial supervision mechanism does not play its own role. Existing accounting firms often give distorted auditing and assurance of enterprise finance for private interests or their own enterprise interests, so that they often do not present convincing data. Furthermore, in order to maintain and continue cooperation, accounting firms do not want to disclose the financial problems of state-owned enterprises actively, so that they lack initiative.

Rights and liabilities of enterprise internal personnel are not clear. The current state-owned enterprise generally has both a financial director and a chief accountant. Some functions of the two overlap, resulting in the unclear hierarchical structure. The rights and liabilities can be clearly defined if the government department takes into account specific situations and specially assigns permanent staff. If the enterprise is managed by general manager and does not refine above levels, the subordinate relations and specific duties will be unclear. When there is a problem, both of them may want to solve it or neither of them pays attention to it. This will reduce the working efficiency. There are still problems involved in the ownership of internal audit institutions. Currently, most of the internal audit institutions are managed by the general manager. Some of them are relatively independent and 
managed by the board of management. That the auditing department performs duties is to apply auditing supervision on clients of different levels. The supervision status of the financial personnel is also very awkward. According to regulations, financial personnel have wide supervision power. Financial personnel at all levels have the obligation to supervise the financial decisions of state-owned enterprises. But there is no clearer laws in this respect, making the real implementation of supervision become difficult.

\section{The Countermeasures for Financial Supervision System of State-owned Enterprises}

\subsection{Specifying responsibility contents}

To supervise business capital. Some enterprises are equipped with the financial settlement center, which is used to gain capital statistics and capture capital flow data through the platform of financial settlement, rather than simply settle funds. This helps enterprises to strengthen the supervision and management of actual running situation of funds, so that they can to reduce or avoid capital risks by the way of centralized capital business. At the same time, the state-owned enterprise should carry out funds transactions in strict accordance with national regulations, establish a strict examination and approval system in the enterprise and control approaches of the funds settlement properly.

To play the role of supervision and administration commission in enterprise assets supervision. China has set the State-owned Assets Supervision and Administration Commission to carry out certain supervision, management and control of various assets. For example, if the grass-roots branch company has a foreign investment project, it should first submit a feasibility report and then implements investment with the unanimous approval. It should control cash flow properly and take responsibility for the maintenance and appreciation of assets value.

To supervise financial reports. The accuracy of an enterprise's financial information is the basis for the enterprise to carry out self-judgment and integration. The financial reporting system should be established and improved to ensure the accuracy and timeliness of financial information from the source. It is necessary to implement the financial statistics work of various departments carefully, making related data reflect the current financial and operating situation of the enterprise. Some other means such as verification can also be adopted to ensure the reliability of data.

\subsection{Strengthening the fundamental construction}

It should ensure that four parts of functions in the corporate governance structure do not involve in some problems, including function overlapping and cross.

The decision-making power of the state-owned enterprise is mastered by the management centered on the board of directors. They are responsible for all major decisions related to the enterprise, so that they have direct effects on the corporate finance. To ensure the reasonable and effective work of the board of directors, the board of directors should be separated from administration, so as to keep its independence and integrity. The board of directors can set up the finance committee and other organizations.

Normal financial supervision can strengthen regular supervision, which can achieve authorization constraints in a certain range to ensure the good running of the enterprise. Specialized personnel can be employed to conduct capital budget to strengthen the capital budget constraints, and meanwhile, the budget should run through the whole enterprise operation. Comparing the final cost with capital budget, the corresponding rewards or punishments can be given to relevant personnel according to the comparison results. It is essential to strengthen the financial management awareness of enterprise personnel, giving full play to the role of capital budget.

To introduce the performance evaluation system. The state-owned enterprise should refer to the development model of excellent enterprises and bring performance evaluation into the assessment of work. According to the actual situations of state-owned enterprises, the performance evaluation should include financial information and non-financial information. In other words, the enterprise profit situation as well as the internal innovation and development of the enterprise should all be taken into 
account in staff evaluation. Finally, corresponding rewards and criticism should be given to relevant employees according to the evaluation results.

\section{Conclusion}

The financial supervision system of state-owned enterprises involves broad scope. To reform state-owned enterprises, it not only needs establish and perfect the supervision system, but also should change the long-lasting operation concept of state-owned enterprises. China has made some achievements through continuous exploration. However, it still needs to continue the deepening reform to realize the self-improvement of state-owned enterprises.

\section{References}

[1]. Li Kai. On the Supervision System of State-owned Enterprise Financial Management [J]. Management \& Technology of SME, 2016, (12): 54-55.

[2]. Zhou Liang. Brief Analysis of the Supervision System of State-owned Enterprise Financial Management [J]. China Township Enterprises Accounting, 2016, (11): 169-170.

[3]. Li Dezhi. Research on the Supervision System of Financial Management in State-owned Enterprises [J]. Modern SOE Research, 2016, (18): 6.

[4]. Liu Guojun. A Study of Supervision System in the State-owned Enterprise Financial Management [J]. Accounting Learning, 2016, (17): 56-57.

[5]. Cheng Liang. On the Study of Supervision System of Financial Management in State-owned Enterprises [J]. China Collective Economy, 2016, (13): 128-129.

[6]. Xu Xinrui, Yao Rao. Research on the Supervision System of State-owned Enterprise Financial Management in China [J]. Brand, 2015, (9): 151-152. 